\title{
Comparative Study of the Responses of Three Clay Deposits to Deferration by an Organic Acid
}

\author{
${ }^{1,2}$ D.O. Folorunso \\ ${ }^{1}$ Department of Metallurgical and Materials Engineering, Federal University of Technology, Akure, Nigeria \\ ${ }^{2}$ Africa Materials Science And Engineering Networks: A Carnegie-IAS (RISE) Networks.
}

\begin{abstract}
The comparative responses of three different clay deposits to iron removal by leaching, using oxalic acid have been studied. The sieve analysis of the clays was done to ensure uniform size distribution of grains. Different characterization techniques were thereafter employed on the raw clays, using X-ray Fluorescence Machine (ARL 8410), X-ray Diffraction Machine (Philips PW 3710 with PW 1752 graphite monocromator) and Scanning Electron Microscope (XL 30 ESEM/EDX) in order to ascertain the purity levels of the clays. The clays were then treated with oxalic acid of different concentrations $\left(0.4,0.8,1.2,1.6\right.$ and $\left.2.0 \mathrm{~mol} / \mathrm{dm}^{3}\right)$ at different temperatures $\left(30,50\right.$ and $70{ }^{\circ} \mathrm{C}$ ), agitation speeds $(120,160,200$ and $240 \mathrm{rev} / \mathrm{min})$ for periods of $30,60,90$, 120 and 150 minutes to remove the impurities in them. XRF and Quantitative XRD were again repeated on the leached clay to know the extent of deferration of the clays. Filtrates of the chemical reactions were also taken at the different combinations of treatment parameters and analyzed, using the Atomic Absorption Spectrometer (AAS) to further ascertain the quantity of iron removed. The exercise revealed that: the iron contents reduced by 53.4, 80.61 and $48.27 \%$ in Ifon, Ipetumodu and Iselin clays respectively.
\end{abstract}

Keyword: Characterization, defferation, Filtrates, Leaching andPurity.

\section{Introduction}

Clay is a hydrous alumino-silicate $\left(\mathrm{Al}_{2} \mathrm{O}_{3} \cdot 2-\mathrm{SiO}_{2} \cdot 2 \mathrm{H}_{2} \mathrm{O}\right)$ [1], and an essential resource in porcelain and ceramic manufacturing, production of paper, pigments, and fillers [2,3]. It is formed by the mechanical and chemical breakdown of rocks. Depending on the atmospheric and geological condition of deposition, as well as the degree of alteration of the clay, iron (hydr) oxides (usually $\mathrm{Fe}^{3+}$ forms) are commonly precipitated or adsorbed to the clay surfaces or admixed as a separate phase $[4,5]$.

The natural clays have different compositions, and the presence of some types of minerals can sometimes be a limitation for some applications [6]. Iron (hydr) oxides make much of the clays unusable for engineering application due to insufficient whiteness [3], reduction of thermal stability and the consequent reduction of refractoriness of products [7]. So, for the reasons mentioned above, the quality of clay is measured in terms of iron content $[6,7,8]$. Some researchers have developed different physical and chemical techniques (and recently microbiological) with the purpose of removing the ferric iron present as oxide or hydrated oxide in the clay. These techniques generally include magnetic separation, froth flotation, selective flocculation, size separation by hydrocyclones, and leaching with inorganic acids[3,7]. However, Hydrometallurgical defferation, using an organic acid (oxalic acid)was employed in this research in order to preserve the crystal structures of the clays and to be able to do effective comparison of the relative responses of the various clays to the treatment.

\section{Materials And Methods}

The materials used in the research work were raw clays from some deposits in the South Western part of Nigeria; Ifon in Ondo State, Ipetumodu in Osun State and Iseyin in Oyo State, 99.8\% purity oxalic acid, iron standard for use in the Atomic Absorption Spectrophotometer (AAS) for determination of iron contents in clays, Herzog organic binder and deionized water.

\subsection{Preparation of the Raw Clays for Analyses}

The clay samples after being mined from the various deposits were separately washed in water and the deleterious particles in them were removed by decantation. They were then drained in Plaster of Paris (P.O.P.) mould for effective removal of the water. They were finally dried in the sun for three days and in the oven at 90 ${ }^{\circ} \mathrm{C}$ for 8 hours. After drying, the clay samples were jaw crushed and ground in a Rawwley Sussex grinder to finer size.

\section{2 sieve analysis}

Sieve analysis was carried out on the three clays using Microtrac FLEX 10.5.4 Filter enabled analyzer. $20 \mathrm{~g}$ of each of the clays was fed into the machine at a time, with a loading factor of 0.0173 , transmission rate of 0.851 and allowed to run for 10 seconds. The average sieve size was found to be about $100 \mu \mathrm{m}$ for the three 
clays. The results are as presented in Fig. $1-3$. The bulk of the three clays were therefore sieved to $100 \mu \mathrm{m}$ for subsequent analyses carried out on them, in order to ensure uniformity.

\subsection{Analysis of Test Samples}

Analyses of the three clay samples were carried out using Scanning Electron Microscopy/Energy Dispersive Spectroscopy (SEM/EDS), X-Ray Diffraction (XRD) and X-Ray Fluorescence (XRF). For this purpose, Scanning Electron Microscope (model JEOL 840), X-Ray Diffraction Machine (Philips PW 3710 with graphite monocromator, model PW 1752), X-Ray Fluorescence Machine (Model ARL 8410) and Atomic Absorption Spectrometer (AAS) Machine (model Spectre AA 220 FS) were used.

\subsubsection{Scanning Electron Microscopy (SEM) analysis}

Morphological, qualitative and quantitative analyses of the clay samples were carried out using SEM. All the samples were carbon coated in order to make the surfaces conductive. Carbon coated samples were then examined directly with the scanning electron in order to reveal the clays' morphologies and their qualitative and quantitative analyses via the attached EDS facility. The results are as presented in Fig. $4-6$.

\subsubsection{X-ray Diffraction (XRD) Analysis}

Representative samples of the clays were milled to fine particles. Phases within the samples were identified by powdered X-ray diffractometry method. The samples were first subjected to X-ray scanning using the Philips PW 3710 with PW 1752 graphite monocromator and a Cu-anode. After X-ray scanning of the samples, mineral peaks were identified using X "Pert High Score Plus software. The background and peakpositions were identified and based on the peak positions and intensities; a search-match routine was performed. The results are as presented in Fig. $7-9$.

\subsubsection{X-Ray Fluorescence (XRF) Spectroscopy Analysis}

Semi-quantitative analysis of the major elements and oxides within the raw and defferated clay samples was done by X-ray Fluorescence Spectroscopy using a Magi "X Pro XRF spectrometer (Model ARL 8410). For this purpose, a mass of $8 \mathrm{~g}$ of each of the powdered clay samples was mixed with $2 \mathrm{~g}$ of Herzog organic binder. The organic binder contained $90 \%$ cellulose and $10 \%$ wax. The mix was further ground and homogenized using a mill. The homogenized samples were placed in an aluminum cup and hydraulically pressed into pellets under very high pressure of 20 tones for 60 seconds. This was done to ensure sample integrity under the vacuum and a consistent surface to receive the X-rays. The results for the three different clays are presented in TABLE 1 .

\subsection{Iron Removal from the Clays}

The raw clay samples were subjected to defferation by leaching using oxalic acid. For iron oxide removal, oxalic acid is five times more effective than inorganic acids, and is capable of complexing and reducing iron $[8,9]$. In order to dissolve a mole of iron, three equivalents of oxalic acid are necessary $[8,9]$. The principle of iron oxide removal is governed by the equation:

$3_{2} \mathrm{O}_{4}{ }^{2-}+\mathrm{Fe}^{3+}=\left[\mathrm{Fe}\left(\mathrm{C}_{2} \mathrm{O}_{4}\right)_{3}\right]^{3--} \quad$ (1)

The purification process involved treatment of specimens from the clay samples with different oxalic acid concentrations of $0.4,0.8,1.2,1.6$ and $2.0 \mathrm{~mol} / \mathrm{dm}^{3}$.Each clay specimen aggregate was agitated at different speeds of 120, 160, 200 and $240 \mathrm{rev} / \mathrm{min}$., at temperatures of 30,50 and $70{ }^{\circ} \mathrm{C}$ for periods of $30,60,90,120$ and 150 minutes. These parameters were chosen so as not to disrupt the crystal structures of the clays. In the process, $10 \mathrm{~g}$ of clay specimen and $50 \mathrm{~cm}^{3}$ of prepared oxalic acid solution were introduced into a flat-bottom flask and put inside the Labcon Shaking Incubator, models $3081 \mathrm{U}$ and 5082U for agitation at pre-set temperature and time.

On the expiration of the set time, the flask was removed, allowed to cool and filtrates taken for chemical analysis in order to determine the $\mathrm{Fe}_{2} \mathrm{O}_{3}$ content, using the Atomic Absorption Spectrophotometer (AAS). The results of which are shown in Fig. $10-12$. From the results of this analysis, the best process condition, which comprised the optimum oxalic acid concentration, treatment temperature, agitation speed and time, was established for each of the clay deposit. The products from the optimum leaching processes were again analysed using the X-ray fluorescence in order to determine the exact quantity of iron removed (TABLE $1)$. 
3.1 Sieve Analysis of Clay Samples

III. Results And Discussion

The results of the sieve analysis of the three clays are as shown in Fig. 1 to 3.

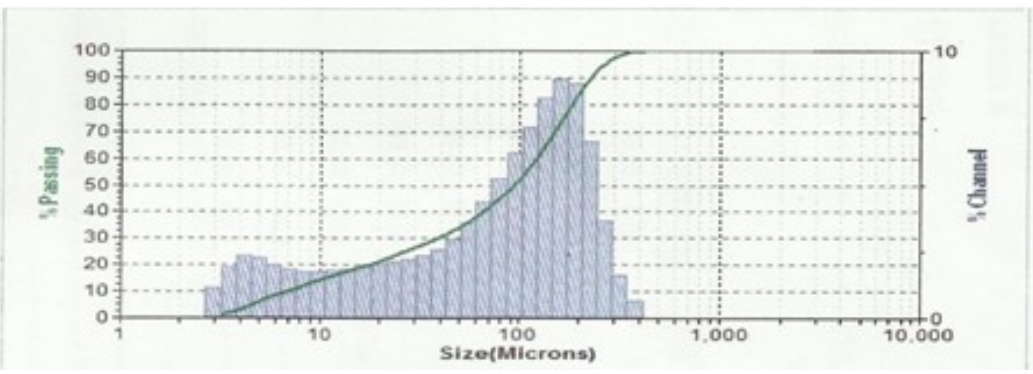

Figure 1: sieve analysis of ifon clay

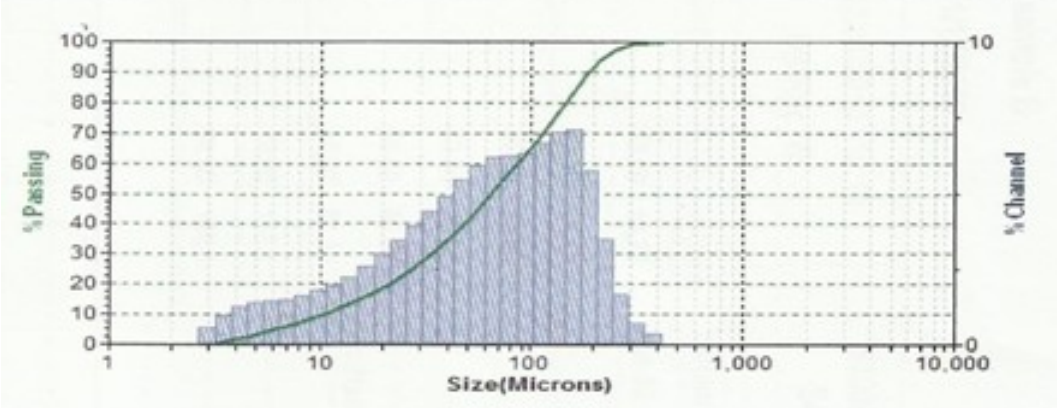

Figure 2: sieve analysis of ipetumodu clay

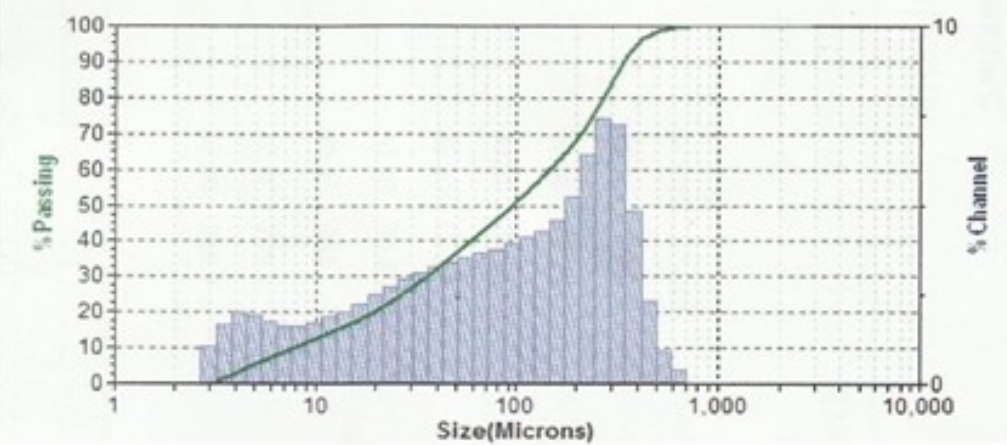

Figure 3: sieve analysis of iseyin clay

Each of them shows an average sieve size of $100 \mu \mathrm{m}$. This accounted for the sieving of the bulk of each of the three clays to $100 \mu \mathrm{m}$, in order to ensure uniformity throughout the course of the remaining work.

\subsection{Scanning Electron Microscopy (SEM)}

The results of the SEM are shown below:
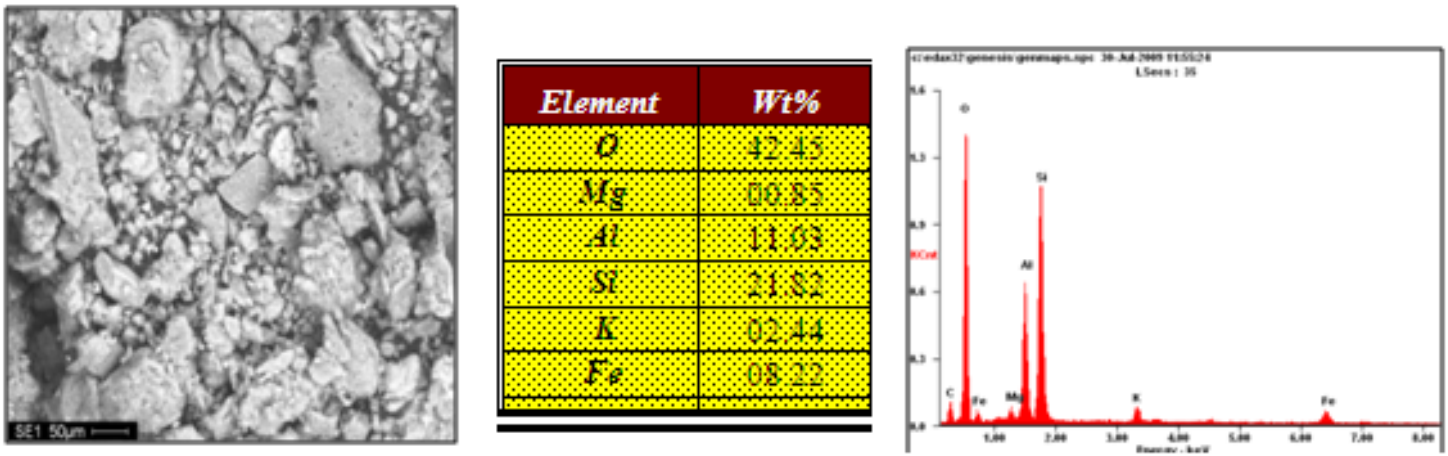

Figure 4: SEM micrograph (X500)of clay particle sizes and EDS pattern for Ifon clay sample. 


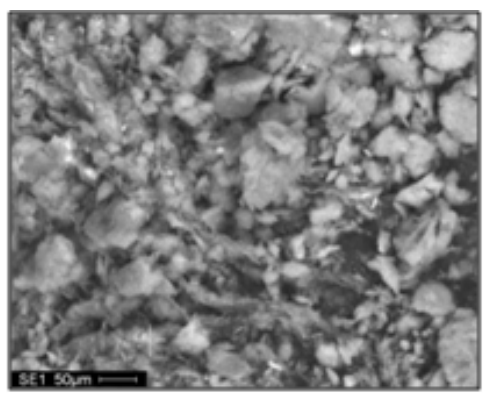

Element 0 Wto

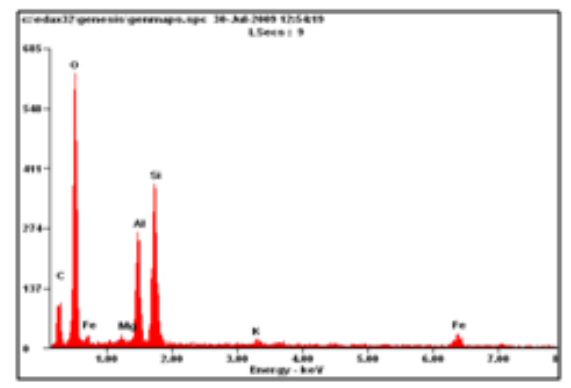

Figure 5:SEM micrograph (X500) of clay particle sizes and EDS pattern for Ipetumodu clay sample.
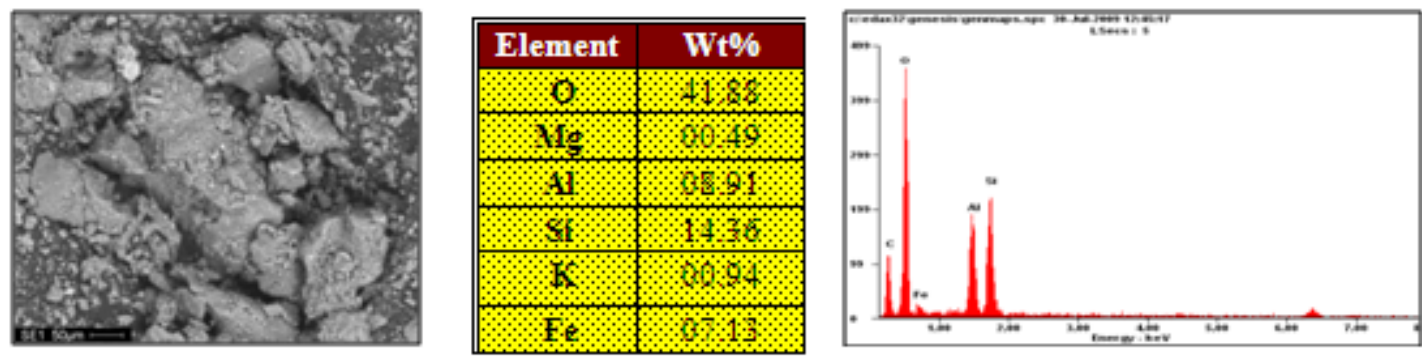

Figure 6:SEM micrograph (X500) of clay particle sizes and EDS pattern for Iseyin clay sample.

Fig. 4 - 6 are the results of the SEM/EDS analyses for the three clay samples, which show the SEM micrographs of the relative sizes of the clay particles at X500 magnification, the spectra depicting the peaks of the elements present and the EDS analyses showing the relative abundance of the various constituents of the clays in weight $\%$. All the clay samples contained more than $6 \%$ of iron, principally in the iron oxide mineral, with Ifon clay having the highest value of $8.22 \%$.

\subsection{X-ray diffraction (XRD) analysis}

Fig. 7-9 show the XRD analysis of the three clays.

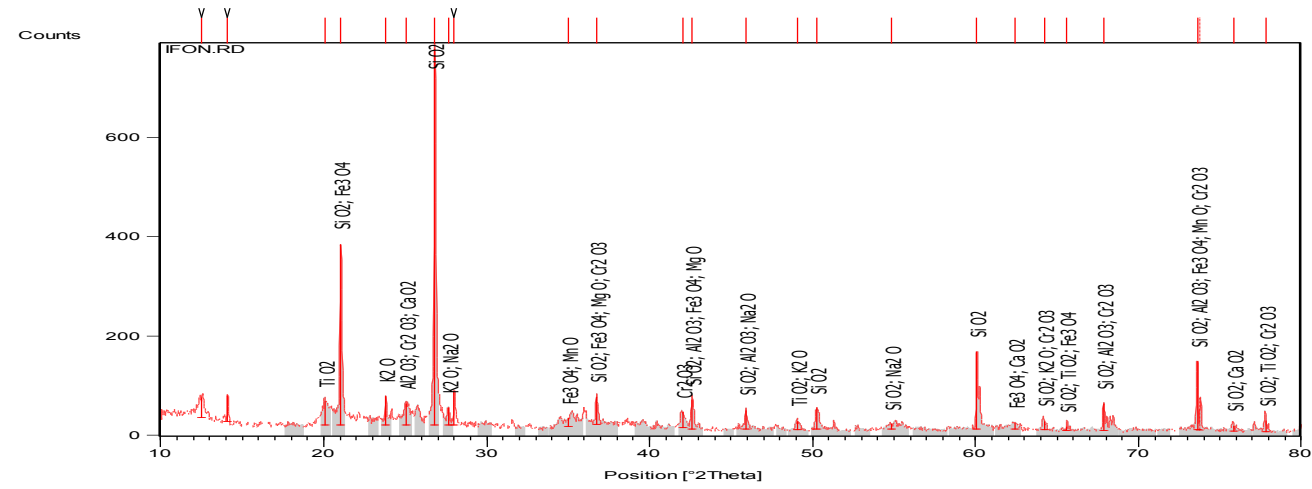

Figure 7: X-ray diffraction pattern for Ifon clay 


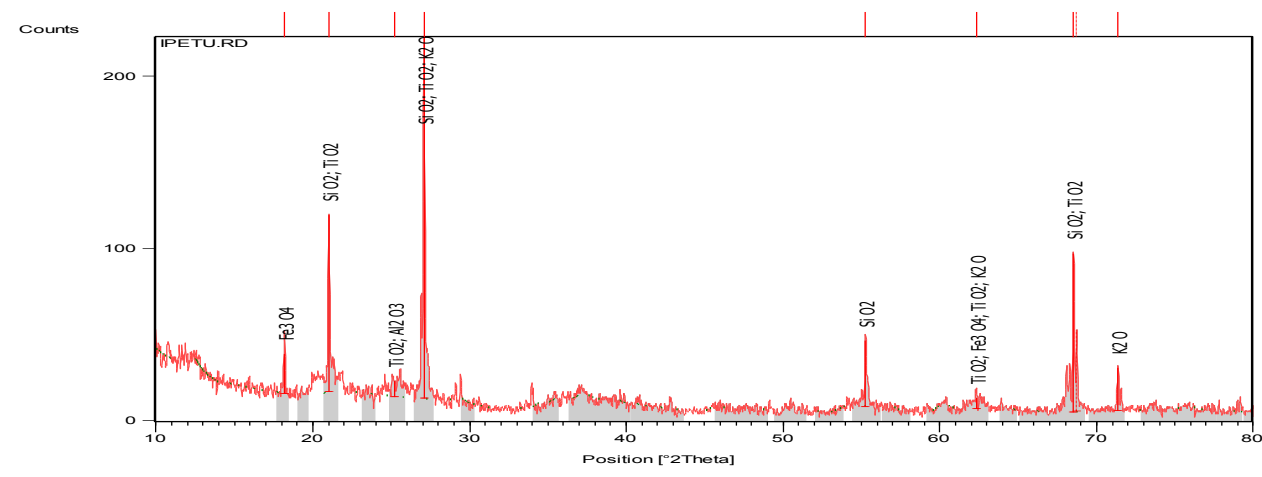

Figure 8: X-ray diffraction pattern for Ipetumoduclay

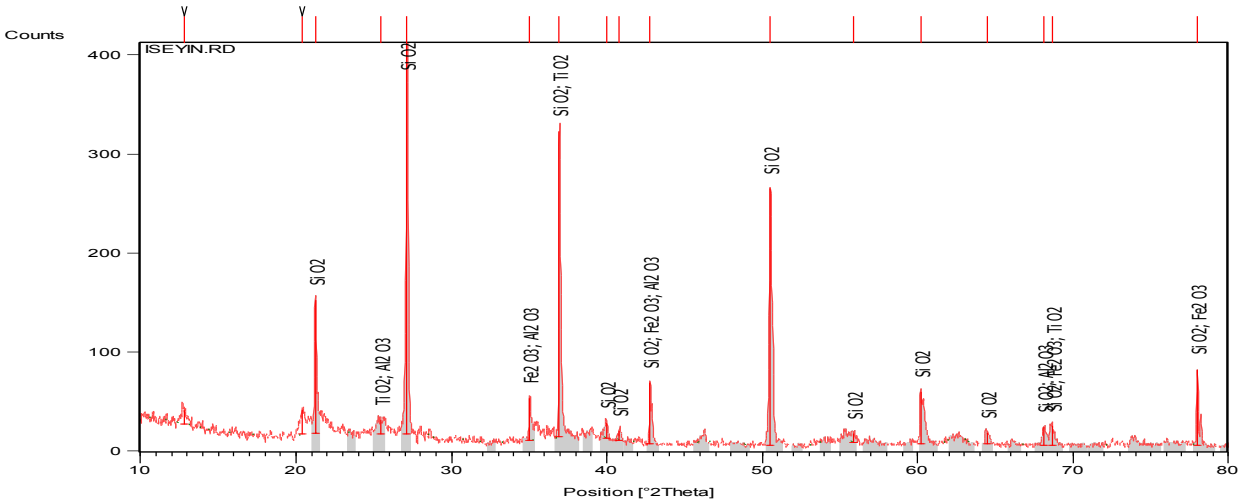

Figure 9: X-ray diffraction pattern for Iseyin clay

The various X-ray diffraction patterns obtained from XRD analysis of the clay samples from the three deposits of Ifon, Ipetumodu and Iseyin are as presented in Fig. 7 - 9 respectively. These were done for qualitative analysis of the clays. These patterns show sharp high peaks for $\mathrm{SiO}_{2}, \mathrm{Al}_{2} \mathrm{O}_{3}, \mathrm{Fe}_{3} \mathrm{O}_{4}$ and sharp but shorter peaks for $\mathrm{K}_{2} \mathrm{O}, \mathrm{MgO}, \mathrm{MnO}, \mathrm{Na}_{2} \mathrm{O}$ and $\mathrm{CaO}$. The heights of the picks indicate the relative abundance of the various minerals present in the clays. Some other oxides were also present but in very negligible proportions.

Table 1: XRF Analysis of the Raw and Leached Clays

\begin{tabular}{|c|c|c|c|c|c|c|}
\hline \multirow{2}{*}{ Oxides } & \multicolumn{2}{|c|}{ Ifon Clay } & \multicolumn{2}{|c|}{ Ipetumodu Clay } & \multicolumn{2}{|c|}{ Iseyin Clay } \\
\hline & Raw & Leached & Raw & Leached & Raw & Leached \\
\hline $\mathrm{SiO}_{2}$ & 66.14 & 62.54 & 59.76 & 59.05 & 62.34 & 63.84 \\
\hline $\mathrm{Al} \mathrm{O}_{2}$ & 20.88 & 22.44 & 21.98 & 25.74 & 18.48 & 17.89 \\
\hline $\mathrm{CaO}$ & 0.40 & 3.31 & 0.53 & 3.78 & 0.36 & 3.38 \\
\hline $\mathrm{Fe} \mathrm{O}_{2}$ & 6.76 & 3.15 & 4.95 & 0.96 & 6.94 & 3.59 \\
\hline $\mathrm{MgO}$ & 0.53 & 0.27 & 0.61 & 1.12 & 0.63 & 0.37 \\
\hline $\mathrm{K}_{2} \mathrm{O}$ & 1.22 & 1.06 & 2.98 & 1.18 & 2.89 & 1.27 \\
\hline$\underset{2}{\mathrm{NaO}}$ & 0.07 & 0.05 & 0.98 & 0.78 & 0.85 & 0.19 \\
\hline $\mathrm{MnO}$ & 0.06 & 0.06 & 0.08 & 0.03 & 0.03 & 0.03 \\
\hline $\mathrm{TiO}_{2}$ & 0.17 & 1.68 & 0.86 & 1.88 & 1.11 & 1.17 \\
\hline $\begin{array}{l}\mathrm{PO} \mathrm{O}_{5} \\
\end{array}$ & 0.03 & 0.17 & 0.05 & 0.05 & 0.03 & 0.03 \\
\hline $\mathrm{Cr}_{2} \mathrm{O}_{3}$ & 0.02 & 0.02 & 0.01 & 0.02 & 0.02 & 0.02 \\
\hline $\mathrm{NiO}$ & 0.01 & 0.01 & 0.01 & 0.01 & 0.01 & 0.01 \\
\hline $\mathrm{V} \mathrm{O}_{2} \mathrm{O}_{5}$ & 0.02 & 0.03 & 0.01 & 0.02 & 0.01 & 0.02 \\
\hline $\mathrm{ZrO}_{2}$ & 0.05 & 0.09 & 0.08 & 0.04 & 0.06 & 0.06 \\
\hline LOI & 5.29 & 5.85 & 7.89 & 5.60 & 6.68 & 8.61 \\
\hline Total & 100.65 & 100.73 & 100.78 & 100.26 & 100.44 & 100.48 \\
\hline
\end{tabular}

The results of the chemical analyses for the three clay samples by X-ray Fluorescence are presented in TABLE 1 . The Table shows semi- quantitative analyses of the clays, revealing the percentages of the principal 
minerals and elements present. The Major minerals contained in them are $\mathrm{SiO}_{2}$ and $\mathrm{Al}_{2} \mathrm{O}_{3}$, which constituted more than $80 \%$, except Isan clay that contained a little above $78 \%$. The other mineral present in some appreciable quantity was $\mathrm{Fe}_{2} \mathrm{O}_{3}$, being between 4.95 and $6.94 \%$. Present in very small quantities were $\mathrm{K}_{2} \mathrm{O}$, $\mathrm{MgO}, \mathrm{CaO}, \mathrm{Na}_{2} \mathrm{O}, \mathrm{TiO}_{2}$ and $\mathrm{MnO}$ minerals. The remaining minerals exist in negligible quantities of less than $0.1 \%$. Their presence has been found not to constitute any threats to the expected performances of the clays at high temperatures [10]. The presence of iron oxide $\left(\mathrm{Fe}_{2} \mathrm{O}\right)$ is detrimental and must be reduced to an acceptable level of less than $1 \%[11]$

The levels of iron oxide in the clays were reduced by $53.40,80.61$ and $48.27 \%$ in Ifon, Ipetumodu and Iseyin clays respectively, indicating that Ipetumodu clay exhibited the best response to defferation by the application of oxalic acid followed by Ifon clay and lastly by Iseyin clay.

\subsection{Atomic Absorption Spectroscopy (AAS)}

The following graphs show the variation of iron removed from the clays at different concentrations of acid.

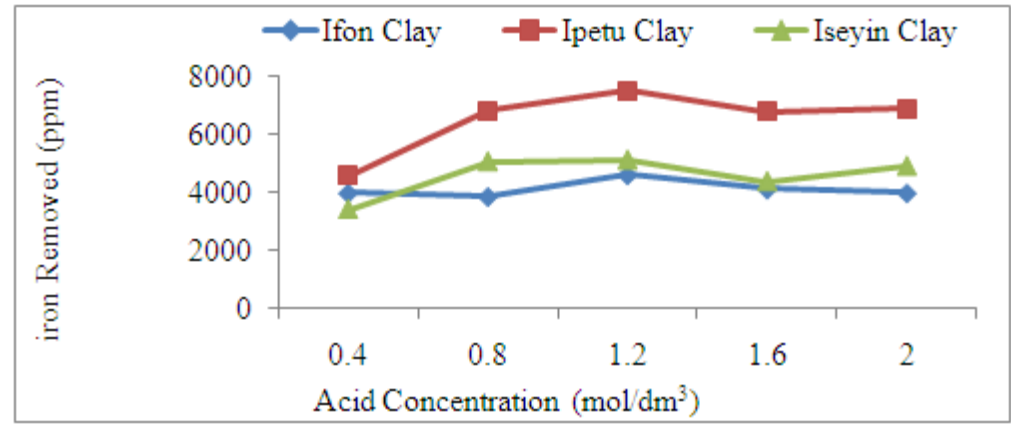

Figure 10: variation of iron removed from Iseyin clay with concentrations in $30 \mathrm{~min}$. at $30{ }^{\circ} \mathrm{C}$ and 200 rev/min

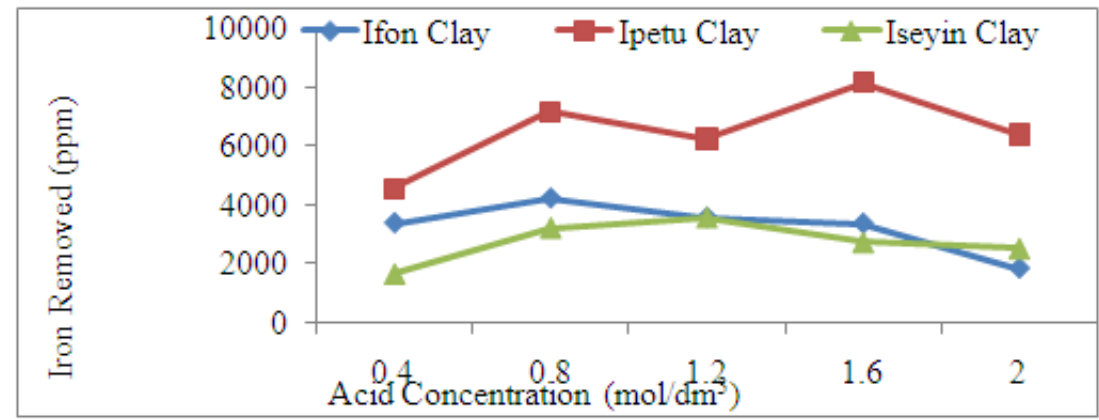

Figure 11: variation of iron removed from Ipetumodu clay with concentrations in $150 \mathrm{~min}$. at $70{ }^{\circ} \mathrm{C}$ and $200 \mathrm{rev} / \mathrm{min}$

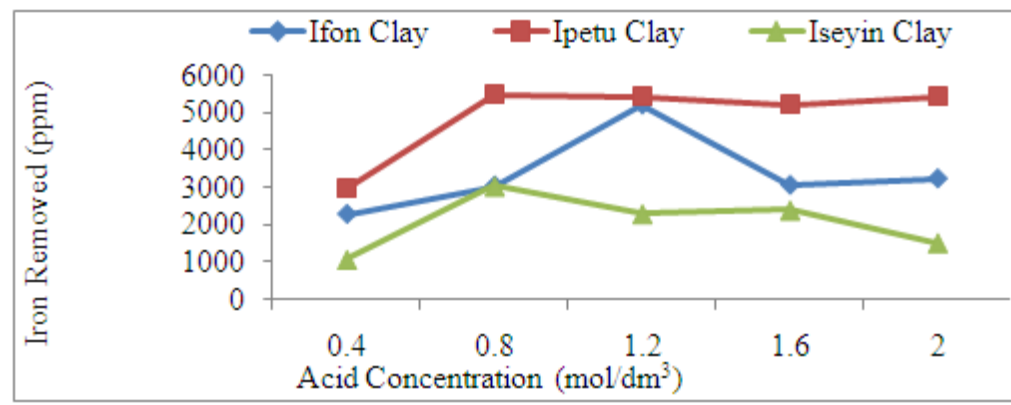

Figure 12: variation of iron removed from Ifon clay with concentrations in $90 \mathrm{~min}$. at $70{ }^{\circ} \mathrm{C}$ and 240 rev/min

All the graphs (Fig. 10 - 12) indicate that the amounts of $\mathrm{Fe}_{2} \mathrm{O}_{3}$ removed from the three clays in part per mil ( $\mathrm{ppm}$ ) were more pronounced in Ipetumodu clay followed by Ifon clay and lastly by Iseyin clay. This trend was noticed at all the combinations of the purification parameters (concentrations, times, temperatures and agitation speeds) employed in the course of the research. The best leaching parameters were found to be; 1.2 $\mathrm{mol} / \mathrm{dm}^{3}$ of oxalic acid at $70{ }^{\circ} \mathrm{C}$ in $90 \mathrm{~min}$ and $240 \mathrm{rev} / \mathrm{min}$ for Ifon clay, $1.6 \mathrm{~mol} / \mathrm{dm}^{3}$ of oxalic acid at $70{ }^{\circ} \mathrm{C}$ in 
$150 \mathrm{~min}$ and $200 \mathrm{rev} / \mathrm{min}$ for Ipetumodu clay and $1.2 \mathrm{~mol} / \mathrm{dm}^{3}$ of oxalic acid at $30^{\circ} \mathrm{C}$ in $30 \mathrm{~min}$ and $200 \mathrm{rev} / \mathrm{min}$ for Iseyin clay, corresponding to $5183.2,8124.0$ and $5139.8 \mathrm{ppm}$ of iron removed respectively. This observation further corroborates the results obtained from the XRF analysis, in which Ipetumodu clay gave the best response to defferation treatment, Iseyin clay being the least.

This trend could be as a result of too much of structural iron in the octahedral sheets of Ifon and Iseyin clays which are generally more difficult to remove than the iron in (hydr)oxides because it is located at a distance of several Armstrong $\left(\mathrm{A}^{\circ}\right)$ from the point of closest approach (basal surface) [11]. Structural iron is the iron that substitutes aluminum as the cation of an octahedral sheet in which hydroxyl ions form the anions.

\subsection{XRD Quantitative Analysis.}

Table 2: XRD Quantitative Analysis of Raw and Processed Clays

\begin{tabular}{|c|c|c|c|c|c|c|}
\hline \multirow{2}{*}{ Clay Minerals } & \multicolumn{3}{|c|}{ \% Weight of Clay Minerals Before and after Processing } \\
\cline { 2 - 7 } & \multicolumn{2}{|c|}{ Ifon Clay } & \multicolumn{2}{c|}{ Ipetumodu Clay } & \multicolumn{2}{c|}{ Iseyin Clay } \\
\cline { 2 - 7 } & Raw & Processed & Raw & Processed & Raw & Processed \\
\hline Kaolinite & 5.73 & 9.60 & 20.02 & 38.53 & 39.71 & 36.33 \\
\hline $\begin{array}{c}\text { Muscovite/ } \\
\text { Illite }\end{array}$ & 3.81 & 4.70 & 15.02 & 25.71 & 14.66 & 20.75 \\
\hline Quartz & 41.42 & 37.78 & 23.84 & 16.74 & 39.45 & 36.11 \\
\hline Microcline & 30.90 & 35.20 & 26.10 & 7.65 & 3.10 & 3.38 \\
\hline Plagioclase Albite & 18.14 & 12.70 & 15.02 & 11.36 & 3.08 & 3.43 \\
\hline TOTAL & 100.00 & 99.98 & 100.00 & 99.99 & 100.00 & 100.00 \\
\hline
\end{tabular}

TABLE 2 shows the mineralogical analysis carried out to identify and determine the relative amounts of minerals contained in the clays before and after defferation. The types and quantities of minerals present in any material influence its refractory performance. For refractory materials, the presence of fusible silica (quartz) or microcline is not desirable because they reduce their refractoriness. The most preferred minerals are kaolinites and muscovites/illites. The percentages of these minerals increased appreciably after leaching especially for the Ipetumodu and Iseyin clays. The total percentages of these most-preferred minerals are $64.24 \%, 57.08 \%$ and $14.30 \%$ for the processed Ipetumodu, Iseyin and Ifon clays respectively.

After leaching, there was a great reduction in the quartz/microcline contents in the Ipetumodu clay but no significant reduction in the Ifon and Iseyin clays. The quartz/microcline contents were $72.98 \%, 24.39 \%$ and $39.49 \%$ for the processed Ifon, Ipetumodu and Iseyin clays respectively. Again, on the basis of clay minerals content, Ipetumodu clay has come out to be the best of the three.

Muscovite/illite and kaolinite levels increased as expected in all the clays after purification, but the increase was more noticeable in Ipetumodu clay just as the expected reduction rate in quartz level was more pronounced in it. Hence, on the basis of the quality of the raw clay, the effectiveness of the leaching process and presence of the most desired clay minerals, Ipetumodu clay was found to be the most responsive of all the three clays.

\section{Conclusion}

1. The combination of the four characterization techniques adopted in this study (XRD, XRF, AAS and SEM/EDS) showed consistency in the relative quantities of iron contained in the clays,

2. The application of oxalic acid in the defferation exercise revealed that the optimum conditions of purification were:Ifon clay $-1.2 \mathrm{~mol} / \mathrm{dm}^{3}$ at $70{ }^{\circ} \mathrm{C}$ for $90 \mathrm{~min}$ and $240 \mathrm{rev} / \mathrm{min}$, Ipetumodu clay -1.6 $\mathrm{mol} / \mathrm{dm}^{3}$ at $70{ }^{\circ} \mathrm{C}$ for $150 \mathrm{~min}$ and $200 \mathrm{rev} / \mathrm{min}$, Iseyin clay- $1.2 \mathrm{~mol} / \mathrm{dm}^{3}$ at $30{ }^{\circ} \mathrm{C}$ for $30 \mathrm{~min}$ and 200 $\mathrm{rev} / \mathrm{min}$.

3. Ipetumodu clay, however, showed the best response to defferation as revealed by the characterization techniques adopted.

4. Ipetumodu clay is, therefore, recommended for high temperature applications because of the possibility of removing iron bearing minerals from the clay.

\section{Acknowledgements}

The author wishes to express profound gratitude to the following bodies for their support for the research work: The Federal University of Technology, Akure (FUTA), African Materials Science and Engineering Network (AMSEN), Regional Initiatives in Science and Education (RISE), Science Initiative Group (SIG), Vesuvius South Africa and Tshwane University of Technology (TUT), South Africa. 


\section{References}

[1]. R. Asmatulu, Removal of discolouring contaminants of east Georgia kaolin clay and its dewatering, Turk. J. Eng. Environ. Sci. Vol. 26, 2002, 447-453.

[2]. H. W. Ryu, K. S. Cho, Y. K. Chang, S. D. Kim and T. Mori, Refinement of low-grade clay by microbial removal of sulphur and iron compounds using Thiobacillus ferrooxidans, J. Ferment. Bioeng. 80, 1995, 46-52.

[3]. I. Styriakova and I. Styriak, Iron removal from kaolins by bacterial leaching, Ceram-Silik. 44, 2000, $135-141$.

[4]. E. Murad, Mossbauer Spectra of nontronites structural implications and characterization of associated iron oxides, Z. Pflanzenernähr.Bodenkd.150, 1987, 279-285.

[5]. J. W. Stucki, B. A. Goodman and U. Schwertmann, Iron in Soils and Clay Minerals. D. Reidel, Dordrecht, 1988, 83-350.

[6]. H. H. Murray, Applied Clay Mineralogy, Occurrences, Processing and Applications of Kaolins, Bentonites, Palygorskite-Sepiolite and common clays", Pub.By Elsevier, 2007,188 pages.

[7]. E. Y. Lee, K. S. Cho, H. W. and Ryu, Microbial refinement of kaolin by iron-reducing bacteria. Appl. Clay Sci. 22, 2002, 47-53.

[8]. D. O. Folorunso, S. Aribo, P. A. Olubambi and J. O. Borode, Hydrometallurgical purification of some clay deposits for high temperature applications, Journal of minerals and materials characterization and engineering, 11 (5), 2012, $461-469$.

[9]. C.N. Mulligan, M. Kamali and B. F. Gibbs, Bioleaching of heavy metals from a low grade mining ore using Aspergillus niger. J. Hazard Mater 110, 2004, 77-84.

[10]. Azom, Refractories, An overview, Journal of Materials online at www.azom.com.04/01/11

[11]. M.R. Hosseini, M. Pazouki, M. Ranjbar and M. Habibian, Bioleaching of iron from highly contaminated kaolin clay by Aspergillus niger, Applied Clay Science 37, 2007, 251-257. 